\title{
12. Gender Mainstreaming in Asian Mining: A Development Perspective ${ }^{1}$
}

\author{
Kuntala Lahiri-Dutt and Gill Burke
}

\section{Introduction}

Gender is one of the defining features of mining in Asian countries. This is for several reasons: the traditional involvement of rural and poor women, often from indigenous and ethnic communities, in the mining workforce; the important roles women play in providing for the subsistence of families, leading to a greater burden of negative impacts of mining on poorer women; and lastly, the increasing feminisation of poverty and the informalisation of women's work throughout the Asian countries. The rising commodity prices are expected to result in an expansion of mining in Asia, leading to an intensification of conflicts against social and environmental injustices. Whilst these unresolved issues remain crucial to improving the livelihoods of innumerable people in Asian countries, the expansion may also be seen as providing an opportunity to tackle gender equities that new mining projects might introduce or exacerbate in local communities. This chapter argues that mining in the Asian context needs to be gender-sensitive for socially-just development outcomes. In doing so, this chapter builds a 'development case' for gender mainstreaming in Asian mining and indicates the possible directions such a mainstreaming process should take.

\section{Mining and Gender in Asia}

Asia has a long history of mining metals, mineral ores and gemstones. ${ }^{2}$ The involvement of women as part of the workforce has been one of the characteristic features of Asian mining. Historical records, including oral histories, have revealed that women and men laboured together in mines. Although protective legislation prevents women's fuller participation, women still participate and contribute to mining economies throughout most of Asia today. Women's participation in the mines in the past was not necessarily restricted to artisanal

\footnotetext{
1 We are grateful to Ms Sophie Dowling for her invaluable research assistance in writing this chapter. Thanks also to Dr David J. Williams for extracting occupational data from 2001 Census Reports of India, and other relevant information.

2 We have excluded the oil and gas sectors of extractive industries from this discussion.
} 
and informal above-ground mines or in shallow operations. Evidence exists in Japan and India that women formed an important part of the workforce in large underground mining projects. Understanding Asian mining begins with this key fact.

A popular notion is that mining is a masculine endeavour, impacting on, victimising and marginalising women as a whole in areas where new projects are introduced. The fact of women's participation in a range of work in and around mines in Asia demolishes this myth based on an imagined masculinity associated with mining, blurs the rigid boundaries of gender roles, and illuminates 'industrial work' and 'economic activities' with a gendered light. Once the 'mineworker' is presented as a gendered subject, the mines reposition themselves as gendered places, and 'Asian mining' becomes contextualised as operating within a non-European social and historical milieu that can bring new understanding to both gender and mining.

This chapter analyses the policy implications of gendered work in Asian mining in the context of recent trends in capital mobilisation in the mining sector in Asian countries. The renewed economic focus on Asian nations ${ }^{3}$, has drawn in multinational capital to break 'new ground' and open new resource projects on a gigantic scale. ${ }^{4}$ The decline of mineral reserves in the developed world has shifted mineral and metal production to Asia and its newly growing economies have also shifted market demand to this continent. Cross-capital flows within Asian countries have also helped trigger this enormous mining expansion. As rising Asian economies take up the important roles of both producers and consumers of minerals and metals, a significant transformation is underway in global mining.

The mining industry is not unaware of these trends. Several industry conferences and meetings have taken place in the last few years showcasing the 'Asian' nature of mining requirements, expertise and capital-flows, and a new industry magazine - 'The Asian Miner' - has been spawned. At the same time, international processes and standards of practice have also been developed, including industry guidelines with regard to environmental and social practices. These derive from the International Council of Minerals and Metals (ICMM), a Global Compact funded by nine major multinational mining corporations and the IFC/World Bank. Civil society organisations, such as Oxfam Community Aid Abroad as well as national bodies such as Jaringan Advokasi Tambang (Mining Advokasi Network-JATAM) and mines, minerals and People (m,m\&P) are also

3 The Mining, Minerals and Sustainable Development (MMSD) report of 2002, 'Breaking New Ground', devotes a significant effort to outlining desirable practice in terms of human rights and social-cultural issues around Asian countries, where major mining activities are expected to impact.

4 Examples can be found across Asia especially in extreme areas such as Tibet, the Gobi Desert in Mongolia and Chinese Turkistan. 
active in Asia. These groups have pointed out the almost uniform failure of mining companies to bring socially just development outcomes to Asian mining regions. Research by these organisations has found that mining impacts more negatively on women than men, while men often benefit from the increased work opportunities mining brings.

Although the debates around mining and society in Asia have yet to be 'gendered' in the sense of moving beyond examining the gendered impacts of mining, a rich reservoir of academic literature exists which discusses gender identities and roles in the extractive sector. Relatively new concepts are entering Asian mining literature; for example Corporate Social Responsibility (CSR) is an increasingly-heard term. Thus there is a need to move beyond the 'impacts of mining on women' and to explore how mining could be equally just for both women and men in Asian societies. Gender inclusiveness and equality are integral parts of development. As a key development 'agent' in many lessdeveloped countries and regions, can the mining industry avoid this debate, and if not, what should be its rationale? This chapter aims to explore this question in the general context of Asian mining.

This discussion traces women's agency in a most unusual place of work; just as Asia is an unexpected context for mining. Historically, a simplistic dualism has characterised mining literature; mining itself has been seen as the 'other' of 'normal' farming-based life. Similarly, miners in Europe have been characterised as the quintessential 'others' to 'normal' social life (Burke 1993). At times, this 'otherness' is manifested in class struggles between miners and other groups involving militant or collective behaviour, at others times, it has been manifested in the stereotype of the 'larrikin' mine worker, who has a tendency toward drunkenness, gambling and rioting. These dualistic images have also been highly gendered, pitching the 'hard, unrefined men, distinct and separate from other workers, hewing in mysterious dungeons' (Allen 1981) as the 'other' of women 'hewing cake' at home (Gibson 1992). Examining this 'otherness' of women in mining communities, Gibson (ibid.) found that women's own working class identity grew out of supporting their men. The gendered division of labour in mining communities also created a gendered spatial division between the home and workplace (McDowell and Massey, 1984). In this chapter, we contest this view and challenge the binary view of men=miner and women=home keeper by drawing attention to the fluid gender identities in Asian mining. 
Can one talk about a distinctive 'Asian' mining today? Not much of the exploitative and/or subsistence-based 'Asiatic mode of production' ${ }^{5}$ that Marx observed is valid in modern mining any more. Modern capital, as we noted, is moving to Asia not only from the more 'central' regions of Europe and North America but also across Asia from within. As a consequence, older conceptions relating to centre-periphery relations are no longer strictly valid in the field of mining. This raises the question of whether the modern capital-intensive interventions can justify the use of the term. The diversity of Asia's mining history, extraction characteristics and mineralogy is enormous. We begin with an acknowledgment of the heterogeneity of Asia in every aspect of its history, economy, society and culture. We accept that some of the 'Asian' features of mining in this diverse context would doubtless also be present in similar measure in the less developed parts of Africa and Latin America. Thus we use 'Asia' as a subset for particular part of the world, a convenient category.

Asia's mining history is of immense antiquity. For many centuries mining flourished throughout the continent, but was scattered and relatively small scale and artisanal in nature. Colonialism in the nineteenth and twentieth centuries transformed mining by introducing modern industrial operations. Although colonial mines did not represent an area of capital entry on the scale of agricultural plantations and industries such as jute, they were significant in bringing these peripheral countries into contact with the centre. British Malaya and Dutch Indonesia rapidly became the world's largest tin producers. Coal from French Vietnam formed an important part of global supply. Moreover, these early colonial-era mines began a pattern of mining-led development within Asia. Independent countries such as Siam followed the same mining development model, whilst Japanese coal production expanded rapidly after the Meiji Restoration. ${ }^{6}$

This pattern of mining sector industrialisation and production expansion continued well after the colonised countries became independent, although by the late twentieth century there were some notable changes in the overall mining profile. Tin mining in Malaysia and coal mining in Japan have both ceased and coal mining is now more significant than tin mining in Indonesia. Yet, farming has remained the predominant occupation and only a few Asian countries (as opposed to African countries) can actually be termed 'mineral

5 The term 'Asiatic Mode of Production' was originally coined by Marx to account for a type of society outside the mainstream of Western development, as the term 'Asiatic' was not restricted to the geographical area of Asia. However, the concept came to be one of the most controversial because of the implication that the 'Asiatic' (or feudal) societies could not reach socialism without going through the purgatory of a capitalist development process (see Bailey and Llobera, 1981, for a detailed outline of the debates around the concept). 6 In 1874 Japanese coal production was 280000 tonnes. By 1919 this had risen to 31 million tonnes (Hane 1982: 227). 
dependent ${ }^{\prime 7}$ in terms of scale of mineral production or values. The ex-Soviet states in Asia - especially Kazakhstan, Tajikistan and Mongolia (MMSD 2002: 45-6), figure more highly in ore and metal export dependence than most others.

As stated, historically, mining in Asia has been characterised by the involvement of women. Feminist historians such as Sone (2006: 154-5) and Hane (1982: 2336) have both shown that women formed a major part of the colliery workforce in Japan until around 1946 when they were completely banned. In colonial India the 'modern' coal mining economy also depended heavily on women's labour, often as part of family labour units (Lahiri-Dutt 2000). In more recent times, modern mechanised mines have hired women to operate trucks and other heavy equipment. In some Indonesian coal and gold mines, women operators drive state-of-the-art, mechanised shovels and dozers in open cut mines. At the same time, prohibitions against women workers in industrialised mining gradually relegated women to artisanal and small-scale mining (ASM) and the informal sector (Lahiri-Dutt 2007). Although such forms of 'peasant mining' have a long history in Asia, in many countries ASM is not always officially recognised. ${ }^{8}$

\section{Mining Countries, Gender Equity and Development}

With its long history of gemstone extraction and other forms of mining, China is by far the largest player in industrial mining in Asia, if not globally. In terms of overall scale and magnitude, China's mining industry ranks third in the world, although production statistics remain sketchy ${ }^{9}$. In terms of domestic marketoriented mineral production, women are under-represented in the mining sector in China as compared to other sectors - at least according to official statistics. Estimates are that women comprise only around three per cent of mining and quarrying workers in urban areas (Yao 2006: 239). A 1936 law prohibited women from working underground in mines, although they can still be deployed at the surface and appear to hold a reasonable number of administrative and technical

7 Mineral dependence is the extent of reliance on mineral output as a proportion of gross domestic product (GDP) or the value of minerals in relation to exports and having a close relation to a countries' general level of economic development.

8 In Indonesia for example, small-scale mining and quarrying for industrial minerals by family groups was recognised through the 'People's Mining' Act (Pertambangan Rakyat), but mining for precious metals is still illegal. Consequently, there still are some legal artisanal diamond mines, but ASM tin is illegal.

9 China has about 80000 state-owned mining enterprises and 200000 collectively-owned mines. China is now the largest coal producer in the world, extracting almost 2500 metric tonnes in 2006 (WCI 2007). However, more than 90 per cent of this production came from 22000 small mines (less than 300000 tonnes per year) and more than half from 12000 very small mines. Although it exports a small amount of coal mainly to South Korea and Japan, the rapid expansion of the country's economy has made China a net importer of coal (38 metric tonnes in 2006) which has led it to impose restrictions on coal exports. 
positions - as high as 35 per cent. However, Yao has found there is continued illegal employment of women underground in a range of private and state owned mining operations in China (ibid.: 249-50).

Although India cannot be described as a 'mining country' ${ }^{10}$, the gamut of mineral reserves there, the large number of people who earn a livelihood from mining, and the importance of minerals in sustaining economic growth has made mining a key sector. India is also one of the leading mineral producers in the world; it is the largest producer of mica, second largest producer of chromites, third largest producer of coal and lignite, fifth largest producer of iron ore, and sixth largest producer of bauxite and manganese ore. In recent years, the share of the Mining and Quarrying sector (as referred to by the Census of India, 2001) in India's gross domestic product (GDP) has grown at an average rate of five per cent, and this rate is likely to continue to grow.

Currently, women comprise around 14 per cent of workers in the Indian mining and quarrying sector (ibid.). However, the extent of informalisation of women's labour is evident from the much higher proportion-33 per cent of all workers - amongst those defined as 'marginal workers'.$^{11}$ In State-owned coal mining, women comprise around 5.6 per cent of the workers, but around 17 per cent of marginal workers in the same sector are women. The participation of women is highest in dolomite mining (33 per cent), mica mining (25 per cent), clay mining (23 per cent), stone quarrying (23 per cent), salt extraction (23 per cent), manganese ore mining (21 per cent) and gem stones mining (19 per cent), indicating that women's labour is concentrated in the small-scale or informal mining sector. In gold mining, women comprise 57 per cent of marginal workers, with chromium ore mining also employing women as 38 per cent of the marginal workers. However, official data on mining employment may not reveal the full extent of women's participation in mining activities in India or in other Asian countries. The construction boom that has accompanied Asian economic growth has massively increased demand for building materials such as stones, sand and gravel, which are mostly obtained from small mines and quarries. Since women's labour is concentrated in the informal sector, one can assume concomitant increases in their employment.

Other data on women's employment trends in Asia reveals that gender inequality is particularly concentrated in the mining sector. For example, in

10 Such definitions are restricted to those countries whose wealth is largely derived from the extraction of mineral resources. Australia, Canada and PNG are amongst such countries. Only around three per cent of India's GDP comes from mining and minerals.

11 According to the Census of India (2001), 'marginal workers' were those who did not work for a major part of the year preceding the enumeration (less than 183 days or six months). Marginal workers are often landless labourers or farmers engaged in various informal jobs during the non-cropping season 'Main workers' were those who worked for a major part of the year preceding enumeration, that is those engaged in any economically productive activity for 183 days (six months) or more during the year. 
the Philippines, the only Asian country to rank well in the Global Gender Gap Index, the number of registered women mining engineers from 19272003 was 40. The number of registered male mining engineers for the same period was 2639 (Chaloping-March 2006: 189). The different work performed by men and women and the number of both employed in the mining sector differs significantly to overall national participation rates. According the Global Gender Gap report (WEF 2008), although Philippine women outnumber men as legislators, senior officials, managers, professionals and technical workers, in mining they are concentrated in administrative work - where their numbers are still less than men. Two mines surveyed by Chaloping-March (2006: 193) in 2000 revealed that of 152 managerial positions, only 16 were held by women. Within the production area in the same mines, there were 3714 men employed and only 51 women. This might be explained by the perception in the Philippines as elsewhere, that underground and earth work is out of bounds to women, but does not explain women's unequal employment in the administrative and technical areas of mine operations.

It is well-known that a low level of gender equity is generally related to low levels of economic development. In the mining literature, we also find that high numbers of women engaging in ASM and informal mining is often an indicator of low levels of gender equity. In less developed countries, the labour force is increasingly becoming feminised, but at the same time, women are being employed in more casual jobs. In their study on Africa, Hinton et al. (2006: 13) observed that the gender roles and the status of women in ASM reflected broader societal levels of gender equity and women's empowerment, including: 'women's and men's access to and control of, resources; their ability to attain knowledge or resources, their decision-making capacity or political power; and beliefs or attitudes that support or impede the transformation of gender roles.'

In Asia women also participate in ASM in greater numbers than in formal mining, which suggests that the correlation between gender roles in ASM and those found in the wider society may be a global phenomenon. Around the world the proportion of women engaged in informal mining varies between 10-40 per cent (Lahiri-Dutt, 2008). Levels of participation vary according to the nature of the mineral, production technology, the physical location of the operation and above all the length of time women have been involved in mining. Although it is difficult to find accurate data on the levels of participation and production in informal small mines and quarries, the number of women engaging in ASM throughout Asia is thought to be rising (Caballero 2006; MMSD 2002: 21).

To further explore the correspondence between gender equity and development in Asia, we now turn our attention to some quantitative and qualitative indicators. Simple national performance statistics such as the Global Gender Gap can reveal the close correlation between a countries' level of economic and 
social development and gender equality. Of the participating Asian countries in the 2007 World Economic Forum (WEF) survey ${ }^{12}$, the Philippines ranked sixth and outshone many developed countries, such as the Netherlands (twelfth) and Australia (seventeenth). However the gender equality rankings of other participating Asian countries were generally low. Those with large mining sectors were particularly so-for example China ranked 73, Indonesia 81 and India 114. ${ }^{13}$ A comparison of the WEF rankings with the UNDP's Human Development Index (HDI $)^{14}$ demonstrates the positive correlation between overall levels of human development and gender equality. The UNDP Gender-Related Development Index ${ }^{15}$ (GDI) highlights the differences between development outcomes for men and women. In terms of individual Asian countries, both the UN's 2007/2008 GDI report and the Global Gender Gap Report rank China 73. Women's labour force participation is 76 per cent as compared with 88 per cent for men but women's income is estimated to be just over one half of men's. India's UN GDI rank is 114, closer to the Global Gender Gap Report rank of 113. Similarly, opportunity and income levels show considerably high levels of inequality as the average income of women is just over one quarter that of men's. The female labour participation ranking for India, low as it is (36 per cent for women as compared with 84 per cent for men), does not reveal the full extent of female participation since it does not include marginal workers or those in the informal sector. Indonesia ranks 81 in the Global Gender Gap Report, but 94 according to the UN's GDI. Indonesian women's labour force participation is 53 per cent to men's 87 per cent and their income is estimated to be on average just less than one half of men's.

12 WEF annually surveys gender differences in attainment in four key areas (economic participation and opportunity, political empowerment, educational attainment and health and survival) between men and women across 128 countries in the world. Of the ten highest ranked countries, eight are from west and northern Europe. Comparisons between the 2008 Global Gender Gap Index and the Global Competitiveness Index and GDP per capita confirm this correlation. The report's authors conclude, 'while correlation does not prove causality, it is consistent with the theory and mounting evidence that empowering women means a more efficient use of a nation's human talent' (WEF 2008: 20)

13 Disaggregated scores for the four separate areas measured reveal differences hidden by the aggregate country rankings. China for instance is ranked 60 for women's level of economic participation and opportunity, but is actually close to the bottom in terms of health and survival at 124. India has a particularly poor rank for economic participation and opportunity at 122 - close to the bottom of the scale - but ranks 21 for women's political participation, a result of the Constitutional provision reserving 33 per cent of seats for women in local level elections. Only the Philippines retains a consistently high rank in terms of outcomes for women across all four areas. Among regions of the world, Asia scores second lowest in terms of women's economic participation and opportunity - behind Latin America and Sub-Saharan Africa. Performance in terms of women's educational attainment and health and survival is similarly low relative to other global regions.

14 The Human Development Index or HDI is a composite index that measures a country's achievements in three basic areas of human development: health, knowledge, and a decent standard of living. Health is measured by life expectancy at birth; knowledge is measured by a combination of the adult literacy rate and the combined primary, secondary, and tertiary gross enrolment ratio; and standard of living by GDP per capita (Purchasing Power Parity US\$).

15 Each country's GDI is worked out as a proportion of their HDI. The GDI rankings are similar to the Global Gender Gap Index and the HDI - with predominantly the same developed countries making up the top 20, with some variations in place of rank. 
Qualitative differences in terms of variables help to explain Indonesia's different rankings. The higher Gender Gap Report ranking is due in part to the relatively higher number of Indonesian women that are found in professional and technical work - 42 per cent as compared with 58 per cent of men. In India only 21 per cent of women as compared with 79 per cent of men are employed within this work sector. In Mongolia, this variable also explains a significant difference in rankings, with the UN GDI ranking Mongolia 100 and the Global Gender Gap Report ranking it 62. Mongolia demonstrates some surprising gender trends in terms of economic participation and opportunity. The level of female labour force participation is 56 per cent to men's 83 per cent, literacy levels are equal between women and men at 98 per cent. A higher proportion of Mongolian women are employed in professional and technical work - 66 per cent as compared with 34 per cent of men, however women make up only 30 per cent of legislators, managers and senior officials compared with 70 per cent of men, and-despite impressive levels of equality in terms of education and literacy —-women's average earnings are half that of men.

Mongolia's example brings us to qualitative variables that are not included in quantitative ranking exercises to ascertain gender equality (save for the focus on income) These include the often stark but invisible differences between men and women in accessing income, resources and services - the so-called 'feminisation of poverty'. ${ }^{16}$ Understanding why women dominate the ranks of the world's poor requires analysis of poverty as a social and cultural phenomenon-not simply an economic one. Early feminists recognised that women's lower status reflected a wide range of impediments and challenges - not least the challenges of bearing and raising children and the responsibilities of managing a household - particularly following a husband's death, divorce or abandonment.

\section{Gender Mainstreaming in Asian Mining}

The mining industry has generally stayed outside of the gender debate, although recent efforts highlighting women's productive roles in mining may help bring about some change to this. From 2000 onwards international conferences organised by academics, international agencies and NGOs have explored ways to include mining in gender debates. ${ }^{17}$ They also clearly agreed on the importance

16 Feminisation of poverty was one of the key issues debated in the Beijing Platform for Action and was a focus when preparing the Millennium Development Goals.

17 The Australian National University funded a 2004 international workshop on Women Miners in Developing Countries. The International Women and Mining Network (RIMM) initiated by grassroots cooperative mineworkers in Latin America, organised three successive and widely attended conferences in the Philippines, Bolivia and Vizag. Oxfam Australia's International Conference 2002 resulted in an edited publication, 'Tunnel Vision: Women, Mining and Communities'. Two successive World Bank conferences in 2003 and 2005 were held in Papua New Guinea (PNG). 
of bringing gender issues into the purview of the global mining industry. Two recent books show that contrary to the popular view of mining as an exclusively male endeavor, women have contributed and still contribute significantly to this industry (Lahiri-Dutt and Macintyre 2006, Gier and Mercier 2006). However, these efforts have yet to result in discernible changes to the industry's policies, practice and outlook. Gender continues to remain at the periphery of the highly corporatised world of mining as evident from the complete lack of attention to gender in the International Council for Minerals and Metals (ICMM) 2005 'Community Development Toolkit'. This begs the question why Asian countries should undertake gender mainstreaming measures and how they should go about it.

At this point the global consensus for the need to mainstream gender in any development process needs considering-particular so in the Asian context. The relationship of gender to development has continued to grow in significance over the years, along with international debate about the role and status of women and their contribution to economic development. Since 1975, which marked the International Year of Women, the focus has shifted from 'women and development' to 'gender and development' (McIlwaine and Datta 2003). This reflects a number of important ideas that have emerged over this periodthe importance of particular historical, social and cultural trends shaping what we call gender, the roles of men and women in a given society, and the recognition that both women and men contribute to the transformation of their respective status, roles and opportunities. The recognition that social and cultural institutions, including government and religion, play important roles in defining gender roles and relationships has also shaped new approaches to the achievement of gender equity.

Gender mainstreaming as a concept is not new; it was first proposed at the 1985 World Conference on Women in Nairobi and more formally developed at the 1995 World Conference on Women in Beijing. In practice it is a strategy for assessing and making women's as well as men's concerns and experiences an integral part of any institution or operation. The ultimate goal is to achieve gender equality. According to Walby (2005: 321), gender mainstreaming is a practical strategy involving the reinvention, restructuring and re-branding of a key part of feminism, comprising, 'both a new form of gendered politics and policy practice and a new gendered strategy for theory development'. It invokes a vision of gender equality achieved through the mainstreaming process by drawing on notions of 'sameness', 'differences' and 'transformation'.

Since 1995 gender mainstreaming has been established as an intergovernmental mandate, re-affirmed in the follow-up UN General Assembly special session held in June 2000. Almost all member states have begun adopting gender mainstreaming in consensus as a global strategy for promoting gender equity 
and implementing gender mainstreaming across a wide range of national policy areas and institutions. Most Asian countries have now initiated policies and programs designed for implementation in a systematic way, with an embedded approach to gender. Similarly, gender mainstreaming strategies have been adopted by all the international aid agencies - the United Nations, World Bank and International Labour Organisation, and also by the Council of Europe. Practitioners in several development sectors, such as water management, have undertaken gender mainstreaming efforts. The process has not been troublefree, and even now both the concept and its practice remain contested (Daly 2005). For example, the prioritisation of Millenium Development Goals in less developed countries can mean that the competitiveness of an economy takes precedence over equality considerations, thereby perpetuating women's ranks amongst the lower paid in many parts of the developing world.

Can one talk of gender mainstreaming in the mining industry? Mining clearly is a 'gendered industry'. Women are already extensively represented in both the formal and informal mining sectors from the highest to the lowest level. The fact that a woman took up the position as CEO of Anglo American plc, the world's third largest mining multinational, might be seen as evidence that the promotional glass ceiling had been well and truly smashed. ${ }^{18}$ Women in developed countries train as geologists and mining engineers and, in some instances, work as skilled miners. This is less common in Asian countries but gradually many urban and educated women are coming to occupy skilled and even high-level managerial positions within the industry.

However significant, these incremental achievements fall well short of the requirements for gender mainstreaming, which takes a comprehensive approach to gender equity, and requires embedding gender-sensitive practices and policies throughout an organisation's internal structures and processes, as well as external activities. At the upper levels of the formal mining sector women can be said to have gained their position by performing to standards set by men (Rossilli 1997). This is often the case from the beginning of their careers. Although women are often actively recruited to compensate for falling male enrolments, the course syllabus at mining and engineering schools are rarely gender sensitive. As far as can be ascertained, no mining company or corporation has yet introduced gender mainstreaming policies. It is clear that a transformation is required amongst the major players in Asian mining. The key question is whether this can be achieved from within the industry or whether it must wait for further changes in the wider society.

In terms of gender mainstreaming measures in corporatised mining, women could become 'incorporated' in the bottom layer through establishing a 'quota'

18 Although later developments proved that sexism did not end within that company with her appointment. 
for women and eventually some jobs would come to be designated as 'women's jobs' ${ }^{19}$ To avoid the pitfalls of developing initiatives that are little more than tokenistic exercises in gender equity, it is necessary to get the philosophy right with the correct nomenclature established from the outset. It also means that targeted gender initiatives to address areas of inequality and specific priorities for women and men must be taken up. Women-targeted initiatives can be used to complement gender mainstreaming to ensure program sustainability, but must also be supported by a comprehensive institutional framework approach to gender equity.

In Asian mining, gender mainstreaming should involve the assessment of the entire gamut of mining activities as gendered practices, including corporatised, artisanal and informal mining. It should also involve investigating the potential gender impacts of any new mining activity and the integration of men's and women's needs and concerns into any proposed course of action, such as community development projects, procurement chains or mine closure plans. The establishment of gender-sensitive mining and development policies and initiatives by both government and industry are necessary preconditions for achieving these goals.

\section{Approaches to Gender Mainstreaming in Mining}

The current philosophy and approach to gender taken by the extractive industries can be said to reflect three broad approaches to gender. These can be described as the development approach, the human rights approach and the efficiency approach or 'business case'. The development approach is taken by Mason and King (2001) to mean gender equality is a primary goal in all areas of social and economic development. It is a core development issue, 'a development objective in its own right' and 'essential for reasons of fairness and social justice'. Evidence of the importance of this can be found in the ASM sector throughout the world (see the growing number of publications on gender and informal mining practices by Hinton et al. 2003, 2006; Yakovleva 2007; and Lahiri-Dutt 2008). A large number of researchers and those engaged with informality have arrived at the conclusion that gender must be recognised and integrated into broader development policies and initiatives in ASM. The large scale mining industry, however, continues to see 'the community' as ungendered and homogeneous, and remains ambivalent about women's participation in mining.

19 Rees (1998) found that this was largely the way that gender mainstreaming operated in the European Union. 
The evidence base for gender mainstreaming pursued by the major international bodies such as the World Bank's Oil, Gas and Minerals Division derives from the now large amount of research and literature detailing the 'impacts of mining on women'. These studies show that there is a gender bias in the distribution of risks and benefits from mining projects: benefits accrue to men in the form of employment and compensation, while the costs fall disproportionately heavily on women. Similar findings run throughout other studies done in Asian countries inviting foreign mining capital to operate around subsistencebased communities. In her early ethnographic work on the political economy of development in a mining town in Indonesia, Robinson (1986: 64) noted these changes were gendered, that in the change from peasant agriculture to wage labour the women have been subject to a decline in their economic independence'. At the same time, Robinson found, 'women have become more economically dependent on men, changes in cultural forms of the expression of gender have resulted in a decline in some of the restrictions on women's personal freedom which hitherto prevailed in the community' (ibid.).

The efficiency approach or 'business case' for gender equity in mining proposes it as 'good for business', economic growth, and poverty reduction. This approach is rooted in the largely unsubstantiated argument that women are 'better workers' than men. ${ }^{20}$ The World Bank's 2007 Gender Action Plan also follows this line; placing emphasis on gender equality as 'smart economics' and notes that it helps to remove gender-based discrimination to get more efficient business outcomes, because gender discrimination prevents both women and men from reaching their full potential. It is true that the employment of women can do more to encourage global growth than increases in capital investment and productivity improvements (see for example AusAID 2006), but it does not necessarily make women 'better workers' than men in mines even though the Minerals Council of Australia's 2007 publication 'Unearthing New Resources' represents women as the new resource for skills-hungry mining companies.

The rights-based approach to gender mainstreaming in mining is exemplified in the work of Macdonald (2006) and elsewhere in the work of Oxfam's Mining Ombudsman, a range of other mining-focused NGOs and international donor agencies. This approach derives from the Universal Declaration of Human Rights, which states: '(t)he human rights of women and the girl-child are an inalienable, integral and indivisible part of universal human rights'. In India, the rights-based approach to gender mainstreaming in mining has not been fully developed, NGOs and their associates being more concerned with social

20 A whole range of such assumptions, often captured in glossy texts with catchy headings, have been compiled by Harcourt (2006: 13-4) who has critiqued claims such as: 'train poor women for a job and your investment is guaranteed', 'replace poor women with men in a factory and you have a docile and effective workforce for less pay and less trouble'. Such claims are dangerous because they create an image of all women as 'special workers' with special abilities that antagonise men. 
and environmental justice issues. Within civil society organisations, inner tensions remain which can hamper efforts to bring attention to and address gender equity in relation to mining. These tensions within the 'women and mining' movement reveal a need to move away from essentialising women as 'victims' to seeing women as economic agents, bound within differences of class and ethnicity.

\section{Conclusion}

We have shown that despite common perceptions, mining is not a 'nontraditional' area of work for women in many parts of Asia. Women's work in Asian mines also raises the importance of understanding the relationship of class and caste to gender, as mining work is seldom undertaken by educated urban women. That there is no universal category of 'women' in Asia and that 'work' is a defining feature of life for women are essential to understanding gender in Asian mining. It is thus important to bring ethnicity and social realities into focus to properly to debate how gender can be mainstreamed in the extractive industries. Unfortunately many women continue to have the least voice, weakest bargaining power, and are often invisible even to the staunchest feminists. For example, the work demands of women working in metro-based Information and Communication Technology (ICT) have inspired changes in Indian labour laws ${ }^{21}$, but at the same time, the last Labour Commission observed that women must be denied underground mining work (Lahiri-Dutt forthcoming). Women workers in many informal mines work within family labour units, thus it is important to recognise this work forms part of household livelihood strategies on which several family members depend, and ensure that women's access to mining work is supported and not undermined. Because 'women and children' in many Asian countries are legislatively clubbed together, efforts such as ILOIPEC's Child Labour eradication projects have the potential to hinder women's rights to better conditions at work.

In 'engendering' the Asian extractive industries sector we need to remember women's long history of involvement in mining work, as well as tackling the challenges of the gendered impacts of mining and incorporating a gendered

\footnotetext{
21 The 2002 Report of the National Commission of Labour in India notes in its several recommendations in point 6.121 of the Review of Law section (NCL, 2003: 95-6): 'We would recommend enactment of a general law relating to hours of work, leave and working conditions, at the workplace.' However, this 'omnibus law', according to the Commission, 'should' incorporate the 'prohibition of underground work in mines for women workers, (and) prohibition of work by women workers between certain hours'. This well-intentioned report completely ignores women workers in mining although urban-based working-class women such as ragpickers, construction workers and bidi (indigenous type of cigarette) workers do get their due consideration. It does consider the question of night work by women at some length, although the focus of this attention is clearly on the information and communications technology workers.
} 
outlook in community outreach projects undertaken by mining companies. ${ }^{22}$ It is also important to remember the generally restrictive environment within which women work in Asia. As shown in this chapter, in many Asian societies, women still cannot own, hold or transfer assets, apply for credit and are not recognized or able to lay claim to the benefits of a parents' will, or work freely without legal restriction or without the permission of male relatives. Consequently, women's status and economic wellbeing were and in many instances still are entirely dependent on their husband, father or other male relatives. Women's lack of legal, social and political rights all impact on their status, their ability to participate freely and fully in society, to exercise choice and agency and to increase their economic productivity and wealth. At the same time, the number of women engaged in the informal mining sector - characterised by greater insecurity and lower wages - has increased, putting them at greater risk of poverty. In this context, does the extractive industry continue to see women as victims or help them to flourish as full economic citizens, empowering them to build families and communities that are economically strong and sustainable on a long term basis? We hope this chapter will form the basis for a more informed debate on gender mainstreaming in the production and in the outreach processes of the extractive industries in Asia.

\section{References}

Allen, V.L., 1981. The Militancy of British Miners. Shipley: The Moor Press.

AusAID (Australian Government Overseas Aid Program), 2006. 'Gender Equality in Australia's Aid Program: Why and How.' Canberra: AusAID. Viewed 15 January 2011 at: www.ausaid.gov.au/publications/pdf/gender_policy.pdf

Bailey, A.M. and J.R. Llobera (eds), 1981. The Asiatic Mode of Production: Science and Politics. London: Routledge.

Burke, G., 1993. 'Asian Women Miners: Recovering Some History and Unpacking Some Myths.' Paper presented to the Women in Asia Conference, University of Melbourne, 1-3 October.

Caballero, E., 2006. 'Traditional Small-scale Miners: Women Miners of the Philippines.' In K. Lahiri-Dutt and M. Macintyre (eds), op. cit.

22 The concept of 'community development' has not quite matured in the extractive industries sector excepting a handful of (usually) privately owned companies taking up development projects in surrounding communities. That does not necessarily mean that the public sector companies do not have social awareness at all; many of these responsibilities have been ingrained either in precedence or tradition although only a few are written into formal laws. For example, jobs have traditionally been offered to 'land losers' although the number of these jobs have been declining and the awareness that besides those losing land (that is directly affected), there are a large number of people who are 'project affected'. 
CASM (Communities and Small-Scale Mining), 2004. Women and Children Workshop. Communities and Small Scale Mining Annual General Meeting in October, 2004. Colombo: Sri Lanka.

Chaloping-March, M., 2006. 'The Place of Women in Mining in the Cordillera region, Philippines.' In K. Lahiri-Dutt and M. Macintyre (eds), op. cit.

Census of India, 2001. 'Final Population Totals, Government of India, New Delhi.' Viewed 20 January 2011 at: http://www.censusindia.net/

Daly, M., 2005. Gender Mainstreaming in Theory and Practice. Oxford: Oxford University Press.

Gibson, K., 1992. 'Hewers of Cake and Drawers of Tea: Women, Industrial Restructuring and Class Processes on the Coalfields of Central Queensland.' Rethinking Marxism 5(4): 29-56.

Gier, J. and L. Mercier (eds), 2006. Mining Women: Gender in the Development of a Global Industry, 1670-2005. New York: Palgrave Macmillan.

Hane, M., 1982. Peasants, Rebels and Outcasts: The Underside of Modern Japan. New York: Pantheon Books.

Harcourt, W. 2006. 'Making Change Happen' Editorial, Women's Rights and Development, Development, 49(1): 1-6.

Hinton, J., M.M. Veiga and C. Beinhoff, 2003. 'Women and Artisanal Mining: Gender Roles and the Road Ahead.' In G. Hilson (ed.), The Socio-economic Impacts of Artisanal and Small Scale Mining in Developing Countries. Netherlands: Swets Publishers.

, 2006. 'Women in Artisanal and Small-Scale Mining in Africa.' In K. Lahiri-Dutt and M. Macintyre (eds), op. cit.

Lahiri-Dutt K., 2000. 'From Gin Girls to Scavengers: Women in Raniganj collieries, Economic and Political Weekly XXXVI(44): 4213-21.

- 2003. 'Not a Small Job: Stone Quarrying and Women Workers in the Rajmahal Traps in Eastern India.' In G. Hilson (ed.), The Socio-economic Impacts of Artisanal and Small Scale Mining in Developing Countries. Netherlands: Swets Publishers.

, 2006. 'Mining Gender at Work in the Indian Collieries: Identity Construction by Kamins.' In K. Lahiri-Dutt and M. Macintyre (eds), op. cit. 
, 2007. 'Role and Status of Women in Extractive Industries in India: Making a Place for a Gender Sensitive Mining Development'. Social Change, December, 37(4): 37-64.

- 2008. 'Digging to survive: Women's livelihoods in South Asia's small mines and quarries.' South Asian Survey15(2): 217-244.

- (forthcoming). 'Gender and Labour at the Coalface: Making a Place for Women in the Indian Collieries.' In S. Raju (ed.) Feminist Studies in Geography, Oxford University Press: New Delhi.

Lahiri-Dutt, K. and M. Macintyre, 2006. 'Introduction.' In K. Lahiri-Dutt and M. Macintyre (eds), Women Miners in Developing Countries: Pit Women and Others. Aldershot: Ashgate.

McDowell, L. and D. Massey, 1984. 'A Woman's Place.' In J. Allen and D. Massey (eds), op.cit.

McWilwane, C. and K. Datta 2003. 'From Feminising to Engendering Development', Gender, Place and Culture, 10(4), 2003, 369-82.

Mason, E.M. and A.D. King, 2001. Engendering Development through Gender Equality in Rights, Resources, and Voice. Washington D.C.: World Bank.

Massey and J. Allen (eds), 1984. Geography Matters: A Reader. Cambridge: Cambridge University Press/Open University.

MMSD (Mining, Minerals and Sustainable Development), 2002. Breaking New Ground. London: IIED and Earthscan.

NCL (National Commission on Labour), 2003. Reports of the National Commission on Labour, 2002-1991-1967. New Delhi: EconomicaIndia.

Parthasarathy, M., 2004. 'Exploring the Impact of Chromite Mining on Women Mineworkers and the Women of Sukinda Valley, Orissa: A Narrative.' In S. Krishna (ed.) Livelihood and Gender: Equity in Community Resource Management. New Delhi: Sage Publications.

Rees T., 1998. Mainstreaming Equality in the European Union, Education, Training and Labour Market Policies. London: Routledge.

Robinson, K. 1986. Stepchildren of Progress: The Political Economy of Development in an Indonesian Mining Town. Albany N.Y.: State University of New York Press. 
Gendering the Field

Rossilli, M., 1997. 'The European Community's Policy on the Equality of Women: From the Treaty of Rome to the Present.' European Journal of Women's Studies 4(1):63-82.

Sone, S., 2006. 'Coal Mining Women Speak Out: Economic Change and Women Miners of Chikuho, Japan.' In J. Gier and L. Mercier (eds), op. cit.

Walby, S., 2005. Gender mainstreaming: Productive Tensions in Theory and Practice.' Social Politics 12(3): 321-43.

WEF (World Economic Forum), 2008. 'Global Gender Gap Report.' Geneva: World Economic Forum.

Yakovleva, N., 2007. 'Perspectives on Female Participation in Artisanal and Small-scale Mining: A Case Study of Birim North District of Ghana', Resources Policy 32(1/2): 29-41.

Yao, L. 2006. 'Women in the Mining Industry of Contemporary China', in K. Lahiri-Dutt and M. Macintyre (eds), op.cit. 